„Bohemistyka” 2019, nr 1, ISSN 1642-9893

Olesya S. SERGIENKO

DOI: $10.14746 /$ bo.2019.1.4

St. Petersburg State University

\section{Main trends of the current research of Czech paremiology}

Keywords: proverbs, Czech paremiology, Czech paremiography, Slavic paremiology, paremiological minimum, paremiological core

\section{Abstract}

The main goal of this paper is to form a comprehensive bibliography of research on Czech paremiology conducted in the 21 st century and to summarize the main topics of research in this field. The author outlines the main centers of Czech paremiology research and highlights the most important achievements of the modern paremiologists in Czech Republic and abroad.

Czech paremiological and paremiographic traditions date back to medieval times. The oldest collection of Czech proverbs compiled in the end of the 14th century is attributed to a Czech nobleman Smil Flaška z Pardubic. The famous Czech Grammar (Gramatika česká) by Jan Blahoslav (1571) also included a list of Czech proverbs collected by Blahoslav and another monk Matěj Červenka. This list of proverbs was published in 1970 by J. Spilka under the name Česká př́sloví (Červenka, Blahoslav 1970). It is also worth to mention the dictionary of Jacub Srnec z Varvažova $(1582,1599)$ that later, in the 17th century became one of the sources for the famous Jan Amos Komenský dictionary Moudrost starých Čechů za zrcadlo vystavená potomki̊m (1620).

Two outstanding collections of Czech proverbs appeared in the period of Czech National Revival - Českých př́sloví sbirka by Jozef Dobrovský in 1804 (Dobrovský 1963) and the still unprecedented multi-language dictionary Mudrosloví národu slovanského ve př́slovich by F.L. Čelakovský in 1851 (Čelakovský 1949, 1978).
The most meaningful paremiographic collections of the 20th century are Sbirka př́sloví, prüpovédí a pořekadel lidu českého v Čechách, na Moravě a v Slezsku ve dvou svazcich by Václav Flajšhans published in 1911-1913 (Flajšhans 2013), Lidová rčeni by Jaroslav Zaorálek (Zaorálek 1947), and finally Česká př́sloví - Soudobý stav konce 20. století by D. Bittnerová and F. Schindler which first edition came out in 1997 and the second in 2003 (Bittnerová, Schindler 2003). This last work is considered to be the most comprehensive collection of proverbs since F.L. Čelakovský. This dictionary included not just the old Czech proverbs from Čelakovský's collection, but also the results of a large-scale paremiological research conducted by Jozef Spilka in the 1950-70ies, as well as the own research of D. Bittnerová and F. Schindler of the 1980ies (Bittnerová, Schindler 2003, pp. 7-8, p. 279). It was the first major attempt to distinguish the paremiological minimum of modern Czech language and included important information on the number of respondents who recognized the proverbs.

The last decade witnessed a real boom of paremiographic activity both in Czech Republic and abroad, but we shall focus on it later on in this article.

While collecting bibliography of Czech paremiology studies of the last 18 years, several factors became obvious. First, there are several main scientific centers of paremiology research which also focus on Czech paremiology.

First of all, it is the Faculty of Arts of the Charles University in Prague where prof. PhDr. František Čermák, DrSc. conducts his major research of international, Slavic and Czech phraseology and paremiology. F. Čermák was the first Czech linguist who started work on distinguishing the paremiological minimum of Czech and came up with a list of Czech proverbs with the most frequent usage (Čermák 2003b, 2010). F. Črmák is the founder of the Czech National Corpus and the main theoretician of corpus linguistics in Czech Republic, so a lot of his phraseology and paremiology research is based on the data derived from the Corpus (Čermák 2005, 2007c, 2010), he also conducted research of the means of including proverbs in the text (Čermák 2006, 
2009). F. Čermák’s achievments in phaseography and paremiography are highly valued both in Czech Republic and abroad, and thanks to his regular participation in internation conferences (Čermák 2007c, 2010, 2011, 2012, 2013, 2014a, 2016b) and publications in English (Čermák 2009, 2014b), the works of F. Čermák are very well-known in the whole world.

František Čermák is the author and coathor of a number of phraseological and paremiological dictionaries. The 4th volume of F. Čermák's monumental phraseological dictionary Slovník české frazeologie i idiomatiky. Výrazy větné (Čermák 2009b) certainly became a major contribution to the development of Czech paremiography. It lists Czech proverbs along with aphorisms, citations, sayings, etc. Some of these proverbs are provided with equivalents in English, German, French and Russian. And what's even more important - this dictionary is among very few that provide definitions to the Czech proverbs.

This dictionary is considered a unique phenomenon in the context of the world phraseology. This work is not only extensive in its scope and depth, but it is highly innovative from the theoretical, metalexicographic and material point of view as well (especially the material of the fourth volume - Sentential Idioms - brings an unexpected and interesting insight into this area) providing comprehensive lexicographic descriptions (Jarošová 2011, s. 51).

The most recent paremiographic work of F. Čermák is a dictionary Základni slovník českých př́sloví. Výklad a užití (Čermák 2013b). It comprises around 500 Czech proverbs that are most frequently used today, and each proverb is provided with a definition and an illustration of usage.

Another major center of paremiological research in Czech Republic is the Department of Slavonic Studies of the Faculty of Arts at the University of Ostrava. This work is led by doc. PhDr. Eva Mrhačová, who is well known for her paremiographic achievements. In the beginning of the 2000ies Czech, Russian and Polish linguists created several translation dictionaries of proverbs. Among them is the Czech version of a dictionary by D.Świerczyńska and A. Świerczyński Słow- nik przystów w ośmiu językach (2004) compiled by Eva Mrhačová Slovník prísloví v devíti jazycích (Mrhačová, Świerczyński, Świerczyńska 2008).

Another dictionary is the collective work of several authors headed by Eva Mrhačová Západoslovanské paremiologické dědictví (Mrhačová 2010). The dictionary is based on the proverbs that were recognized by 10 or more respondents of D. Bittnerová and F. Schindler and listed in their collection Česká prísloví-Soudobý stav konce 20. stoleti. The authors found parallels to these proverbs in five West Slavic languages - Slovak, Polish, Kashubian, Upper Sorbian and Lower Sorbian. The dictionary also provides definitions to Czech proverbs.

Paremiological research conducted by Eva Mrhačová and her students mostly focuses on the comparative studies of proverbs in Czech, Polish and Russian languages (Mrhačová 2003a, 2003b, 2012, 2014b, 2016; Mrhačová, Plesník, Kupcevičová, Vaida 2017).

Every two years since 2002 the Ostrava University conducts the International Paremiological Conference „Parémie národů slovanských". The conference organization committee is headed by doc. PhDr. Eva Mrhačová. It is certainly one of the most important events in Slavic and Czech paremiology that gathers dedicated researchers of proverbs from all around Europe who later publish their conference papers in the specialized edition „Parémie národů slovanských“ (Koтова 2003d, Котова 2010b, Сергиенко 2008, Сергиенко 2010c, Ваláková 2007, Junková 2005, Mrověcová 2017, Srpová 2003, Šrámek 2003).

Next center of paremiological research is located in Russia at the Department of Slavonic Philology of the Faculty of Arts of the St. Petersburg State University that is very proud to have one of the most prominent Russian phraseologists Prof. Valerij M. Mokienko among its faculty members. V. Mokienko is the author of over 1000 scientific publications in the field of Slavic studies, comparative lexicology and phraseology of Slavic languages, ethnolinguistics, translatology, historical-etymological phraseology and paremiology, general and Slavic lexicography, etc. His paremiographic and phraseographic work is 
highly recognized in the whole world. In his research V. Mokienko touches on the issues of Czech paremiology as an integral part of Slavic paremiology and European paremiology.

Paremiological research at the Department of Slavonic Philology in St. Petersburg is also conducted by Prof. Marina Yu. Kotova, the author of the multilingual Russian-Slavic dictionary of proverbs with English parallels (Котова 2000) who initiated a major sociolinguistic paremiological research in 2003-2004. As M. Kotova describes it herself, the first stage of research was conducted in collaboration with the colleagues from the six Slavic countries: from Byelorussia, Bulgaria, the Czech Republic, Poland, Serbia and Slovakia. Based on the paremiological minimum of Russian language determined by G. Permyakov in the 1970ies, M. Kotova formed questionnaires containing parallels to the 500 Russian proverbs from the list of G. Permyakov in the above mentioned six languages, including Czech. On the basis of 100 questionnaires for each language which were all filled by 100 respondents (mainly students, native-speakers) six summary lists of proverbs with all the variants noted by the respondents were created (Kotova, Raina, Sergienko 2017, p. 176).

Ten years later the paremiological group at the Department of Slavonic Philology of Saint Petersburg State University (O.V. Raina, O.S. Sergienko, A.A. Kolpakova, O.N. Tararaeva) filtered these summary lists through Internet search and found out some current contexts as actualization of the proverbs from the general lists. Four handbooks with the results of this Internet survey - Bulgarian, Czech, Slovak and English - have been published for the University students' seminar of Slavonic Paremiology for MA in Slavistics as supplements to the multilingual dictionary of Slavic proverbs with English parallels. The Czech handbook (Котова, Сергиенко 2013) received a positive review in one of the leading Czech philological journals (Lepilová 2013b).

Scientific interests of M. Kotova lie in the field of comparative Slavic and Slavic-Germanic paremiology, identifying of paremiological minimum for Slavic languages and proverbial parallels in different
Slavic languages. The work of M. Kotova and her associates focuses on the identification of the mutual paremiological core for the Slavic languages and aims at creating of the new improved edition of the multilingual Russian-Slavic dictionary (Kotova 2014; Kotova, Raina, Sergienko 2017).

The problems of Slavic and Czech paremiology are discussed on the regular basis at the two sections of the International Philological Research Conference organized annually at the St. Petersburg State University. These sections are called Slavic Phraseology headed by V.M. Mokienko and Slavonic-Germanic comparative studies headed by M.Yu. Kotova (from 2019 this section will have a new name Slavs in the context of global culture: comparative linguistics, imagology, translatology).

Finally, a big phraseology center is based at the Department of Slavonic Studies of the Faculty of Arts at Palacký University in Olomouc. It is headed by Prof. Ludmila Stepanova, a long-term associate and ex-student of Prof. V. Mokienko. Since 1976, the international scientific conference, The Olomouc Days of Russian Studies has been organised by the Department of Slavonic Studies. At first these were the courses of continuing education for high school teachers of Russian language, but after some time the event took the shape of a specialized international forum that is held every other year. At the Phraseology section of this conference supervised by L. Stepanova one can always hear reports on comparative Slavic or Slavic-Germanic phraseology and paremiology which are later published in „Rossica Olomucensia Journal” (Чекулай, Прохова 2014; Mrověcová 2014; Stepanova 2009).

Year 2013 witnessed the historical reedition of Václav Flajšhans's monumental work Česká přísloví. Sbirka př́sloví, průpovědí a pořekadel lidu českého v Čechách, na Moravě a ve Slezsku. This new edition was prepared by Prof. V. Mokienko (St. Petersburg State University) and Prof. L. Stepanova (FF UP Olomouc) who also enriched it with scientific and historical commentary to a number of dictionary articles. Of special interest is the article by V. Mokienko Václav Flajšhans jako predvoj Evropské unie paremiologické where he stresses the 
scientific significance of Flajšhans's dictionary for European paremiology (Flajšhans 2013).

As O. Fedosov puts it in his article New world order and modern Slavistics, this dictionary proved the fact that the Czech paremiological fund is very close to the fund of German proverbs, and it was only due to bad timing (the dictionary was published just before WWI) that it did not receive all the attention and recognition that it deserved (Федосов 2016). Only today modern paremiologists and phraseologists started talking about the identity of the European paremiological and phraseological core. V. Mokienko dedicated several of his latest reports and papers to this topic. In the introduction to the dictionary V. Mokienko says that the main value of this book is that it depicts Czech proverbs and idioms in the full-scale context of European folklore, it contains parallels in many Slavic languages as well as German, French, English and Latin. It demonstrates the European character of Czech culture, its deep connection with the folklore of other European nationalities (Mokienko 2013b).

The collected bibliography on Czech paremiology represented in this research currently accounts more than 100 scientific papers including doctoral thesis, monographs, chapters in joint monographs, articles in linguistic journals, conference papers, etc. The bibliography also includes some broader phraseological and linguistic research where paremiology is mentioned as one of the aspects. Some other research view proverbs as part of the language picture of the world or as an element of a semantic field. That is why not all the works contain the words paremia or proverb in their titles.

Out of 110 scientific works on Czech paremiology 54 belong to the Russian or Russian-speaking scholars, some of them were published in foreign languages.

The list of paremiographic dictionaries that focus on Czech proverbs or include Czech as one of the languages accounts for 22 positions, 15 of them were published in the $21^{\text {st }}$ century, and most of them are newly created dictionaries, and not reeditions of the old paremiographic works.
While some works are dedicated to the general problems of Slavic paremiology and paremiography, formulate the main principles of paremiological research and touch-base on the most burning topics (Котова 2001; Мокиенко 2012, 2014a; Mokienko 2013a, 2013c), there are still a lot of precise paremiological problems that are being studied. Therefore, what are the main topics of the modern paremiological discourse?

Quite a number of current paremiological research is conducted within the field of cultural linguistics, cognitive linguistics and the the ory of concepts (Кириллова 2010; Наумова 2017; Чекулай, Прохорова 2014; Čermák 2011, 2016b; Mrhačová 2003a, 2003b; Mrověcová 2014, 2017). In the last twenty years due to a scientific boom in these disciplines, many paremiologists and phraseologists have concentrated on such qualities of linguistic units as evaluativity, ability to collect information and distinguish connection with the values.

G.L. Permiakov's theory of pare miological minimum has generated some very interesting research in paremiology and paremiography not only in Russia (Котова 2000, 2001 and other works, Сергиенко 2010b) but also in Czech Republic (Čermák 2003b and other works).

Another popular topic of paremiological research is $1 \mathrm{ing} \mathrm{u}$ is t i c b or row ing of foreign proverbs, proverb acquisition and c a lques (Сергиенко 2014a, Kovár 2017). The main topic of the Phraseology section at the upcoming XLVIII International Philological Conference at the St. Petersburg State University will be „Acquisitions and calques in Slavic phraseology“, so let us see if it attracts any reports on research in Czech paremiology.

The problem of proverb equivalents or proverb parallels in different Slavic languages as well as other European languages is also widely discussed in the current paremiological research (Котова 2004a; Котова, Сергиенко 2013; Сергиенко 2014c; Čermák 2011; Mrhačová, Plesník, Kupcevičová, Vaida 2017; Sergienko 2016). Clo- 
se to this topic is the problem of adequate trans lation of prov e r b s (Сергиенко 2014b, Сергиенко 2016).

A number of linguists focus their studies on proverb trans formations and proverb variants (Сергиенко 2007, 2008, 2009, 2010a, 2015; Čermák 2004, 2010).

Ofinterest is the proverbs' usage in the language of modern mas media, politicaldiscourse and adver t i s e m e n t (Junková 2001, 2005, 2006; Kovář 2017; Srpová 2003; Šichová 2015).

Out of 110 scientific works 25 articles focus on the $\mathrm{co} \mathrm{m}$ p a r a t i ve Slavonic-Germanic paremiological research. As it was mentioned earlier, many works by V. Mokienko describe the common European paremiological core and the international character of paremiological fund of all the languages (Мокиенко 2012, 2013a, 2013b, 2014b, 2014c).

Striving to find the proof of proverbs' usage in modern Czech, many scientists use the methods of corpus linguistics and describe the methods of distinguishing proverbs in the corpora in their articles (Hnátková 2002, 2005; Kopřivová, Hnátková 2013; Čermák 2006).

We believe that the collected bibliography is far from complete, and we shall continue to look for more interesting research on Czech paremiology as well as proceed further with our own research of Czech paremiological minimum, usage of proverbs in modern Czech language, proverb translation and proverbial parallels in Czech, Russian and English languages.

\section{Bibliography}

B a lá k ov á D., 2007, Somatické parémie v komunikácii. In: Parémie národů slovanských III. Ostrava: Ostravská univerzita. s. 63-71.

Č e c ho vá M., 2000, Čeština řeč a jazyk, Praha: ISV.

Č e r m á k F., 2002, Frazém a idiom, Frazém propoziční a polypropozični monosubjektový, Frazeologie a idiomatika, Pořekadlo, Pranostika Př́sloví, Rčení. In: Encyklopedický slovník češtiny. Praha: Nakladatelství Lidové noviny, s. 139$-144,322,332,357$ a 368 .
Č e r m á k F., 2003a, Onomaziologické systémy u propozic a proverbií. In: Parémie národu slovanských. Sborník z konference v Ostravě 20.-21.02 u príležitosti 150. výroči úmrtí F.L. Čelakovského a jeho »Mudrosloví, Ostrava, s. 47-54.

Č e r m á k F., 2003b, Paremiological Minimum of Czech: The Corpus Evidence. In Flut von Texten - Vielvalt der Kulturen. Ascona 2001 zur Methodologie und Kulturspezifik der Phraseologie. Hrsgb. H. Burger, A. Häcki Bufofer, G. Greciano. Schneider Verlag Hohengehren, pp. 15-31.

Č e r m á k F., 2004, Jazyková variabilita: připad př̉sloví. In: Čeština-univerzália a specifika 5, eds. Z. Hladká, P. Karlík, Praha: NLN, s. 99-109.

Č e r m á k F., 2005, Text introducers of proverbs and other idioms, ,Jezikoslovlje” 6 , No 1-2, pp. 57-77.

Č e rmá k F., 2006, Statistické metody hledáni frazémů a idiomů v korpusech. In: Studie z korpusové lingvistiky 2 Kolokace, eds. F. Čermák, M. Sulc. Praha: NLN, s. 94-106.

Č e r m á k F., 2007a, Frazeologie a idiomatika. In: Kapitoly z dějin české jazykovědné bohemistiky, eds. J. Pleskalová et al. Vyd. 1. Praha: Academia, s. 243-248.

Č e r má k F., 2007b, Frazeologie a idiomatika česká a obecná. Czech and General Phraseology. Praha: Karolinum.

Č e r m á k F., 2007c, Proverbs: Linguistic and Lexicographic Approaches versus Etnographic, Logical, Onomasiological and Other. In: 1st Interdiciplinary Colloquium on Proverbs. 1. Colóquio Interdisciplinar sobre Proverbios, Eds. Rui JB Soares, Outi Lauhakangas, Tavira, 5th to 12th November 2007, Actas ICPO7 Proceedings, pp. 197-207.

Č e rmák F., 2009, What One Can Do with Proverbs in Text. In: Csaba Foldes (Hrsg.), Phraseologie disziplinar und interdisziplinar. Gunter Narr Verlag, Tubingen, pp. 307-321.

Č e r mák F. 2010, Frequent Proverbs and Their Meaning. A Proposal of a Linguistic Description (The Core and Paremiological Minima Described). In: 3. Colóquio Interdisciplinar sobre Proverbios. 3rd Interdisciplinary Colloquium on Proverbs. Actas ICP Proceedings, International Association of Paremiology, eds Rui Soares, Outi Lauhakangas, pp. 40-65.

Č e r m á k F., 2011, Dog and cat proverbs: a comparison of English, Czech, Finnish and other languages. In: Proceedings of 4th Interdisciplinary Colloquium on Proverbs, eds. Rui JB Soares, Outi Lauhakangas. International Association of Paremiology (AIPIAP), pp. 131-140.

Č e rmá k F., 2012, Lexical foundations of proverbs, based on data from English, German. French and Czech. In: 5th Interdisciplinary Colloquium on Proverbs, eds. Rui B Soares, Outi Lauhakangas. International Association of Paremiology (AIPIAP), Lisbon, pp. 203-217.

Č e rmák F., 2014a, Numbers in Proverbs. In: Actas ICP14 Proceedings, of the 8. Colóquio Interdisciplinar sobre Provérbios. The 8th Interdisciplinary Colloquium on Proverbs, IAP-AIP (International Association of Paremiology), eds. Rui Soares, Outi Lauhakangas Tavira, pp. 298-305. 
Č e r má k F., 2014b, Pragmatics of Proverbs: Basic Types of Evaluation. In: Actas ICP12 Proceedings, of the 7th Colóquio Interdisciplinar sobre Provérbios. The 7th Interdisciplinary Colloquium on Proverbs, IAP-AIP (International Association of Paremiology), eds. Rui Soares, Outi Lauhakangas Tavira, pp. 259-266.

Č e r m á k F., 2014c, Proverbs: Their Lexical and Semantic Features. In: Proverbium in cooperation with the Institute of the Czech National Corpus, Supplement Series, Vol. 37, ed. W. Mieder. Burlington-Vermont: The University of Vermont.

Č e r m á k F., 2015, Wisdom in Proverbs. In: Bis dat, qui cito dat. Gegengabe in Paremiology, Folklore, Language, and Literature. Honoring Wolfgamg Mieder on His Seventieth Birthday. Eds. Ch. Grandl, K. J. McKenna, Peter Lang Editions Frankurt am Main, pp. 95-98.

Č ermák F., 2016a, Frazeologie a idiomatika: Jejich podstata a proměnlivost názorù na ně, „Časopis pro moderní filologii” 98, č. 2, s. 199-217.

Č e r m á k F., 2016b, Laugh Proverbs. Do They Really Capture Laughing? In: Actas ICP15 Proceedings, of the 9. Colóquio Interdisciplinar sobre Provérbios. The 9th Interdisciplinary Colloquium on Proverbs, IAP-AIP (International Association of Paremiology), eds. Rui Soares, Outi Lauhakangas Tavira pp. 291$-298$.

H 1 a d k á Z., 2007, Lexikografie. In: J. Pleskalová, P. Karlík, R. Večerka, M. Krčmová. Kapitoly z dějin českéjazykovědné bohemistiky. Praha: Academia, s. 164-198 .

H n á t k o vá M., 2002, Značkováni frazémů a idiomů v Českém národním korpusu s pomoci »Slovníku české frazeologie a idiomatiky «. „Slovo a slovesnost” 63, č. 2 , s. $117-126$.

Hnátková M., 2005, Identifikace prísloví v korpusu. In: Jazyky a jazykovéda, Sborník $k$ 65. narozeninám prof. F. Čermáka. Praha, filozofická fakulta Univerzity Karlovy, Ústav Českého národního korpusu, s. 89-97.

Jaro šová A., 2011, A Masterpiece of the Czech and the World Phraseology. „Jazykovedný časopis” 62, č. 1, s. 51-64.

J u n k o vá B., 2001, Frazeologické prostředky současné žurnalistiky. In: K aktuálnym otázkam frazeológie. Nitra: Univerzita Konštantína Filozofa v Nitre, s. $156-167$.

J u n k o vá B., 2005, Parémie v současných psaných publicistických textech. In: Parémie národů slovanských: sborník přispěvkỉ z mezinárodni konference konané v Ostravě ve dnech 10.-11.11.2004. Ostrava: Ostravská univerzita, Filozofická fakulta, s. 54-63.

J u n k o vá B., 2006, Kulturní frazeologie v současné publicistice. In: Komunikacestyl - text. České Budějovice: Jihočeská univerzita, 2006, s. 87-92.

K l é g r A., 2013, Proverbs as speech acts in English and Czech. „Acta Universitatis Carolinae Philologica" 3, pp. 7-29.
K o př i v o vá M., H n á t k o vá M., 2013, Identification of Idioms in Spoken Corpora. In: K. Gajdošová, A. Žáková, Proceedings of the Seventh International Conference Slovko 2013; Natural Language Processing, Corpus Linguistics, E-learning. Bratislava, Slovak Academy of Sciences, s. 92-99.

K o t o v a M.Yu., 2014, K otázce vymezení rusko-česko-slovenského paremiologického jádra. „Lingua Viva” X, č. 19, s. 45-54.

K o to va M., R a in a O., S e rg i e n k o O., 2017, On the Way to the Multilingual Dictionary of Proverbs: Sociolinguistic Experiment and Internet Resources. „ASSEHR: Advances in Social Science, Education and Humanities Research" 72, pp. 176-179.

K o vá ř M., 2017, The function of foreign proverbs in Czech newspapers and other periodicals. In: Soares, Rui JB; Lauhakangas, Outi. 10th Interdisciplinary Colloquium on proverbs: Acta ICP16. Tavira: International Association of Colloquium on proverbs:
Paremiology, s. $480-486$.

K u č e r a K., 2017, Proper names in Czech proverbs and idioms: a historical outline of types and functions. In: Soares, Rui JB; Lauhakangas, Outi. 10th Interdisciplinary Colloquium on proverbs: Acta ICP16. Tavira: International Association of Paremiology.

K u k a 1 P., 2007, Povídáni a hry s českými př́slovími pro děti od 6 do 10 let. Havlíčkův Brod: Grada Publishing, a.s.

L e p i l o v á K., 2013a, Reedice Českých př́slovi Václava Flajšhanse (1911). „Opera Slavica" 23, č. 4, s. 62-63.

L e p i l o vá K., 2013b, »Tetradi paremiografa« petrohradských bohemistů. „Opera Slavica" 23, č. 4. s. 61-62.

M o k i e n k o V.M., 2013a, The problems of Slavic paremiology: linguistical aspects. In: $6^{\circ}$ Colóquio Interdisciplinar sobre Provérbios. The 7-th interdisciplinary Colloquim on Proverbs. Actas ICP2 Proseedings. Tavira: Governo de Portugal.

M o k i e n k o V., 2013b, Václav Flajšhans jako předvoj Evropské unie paremiologické. In: V. Flajšhans, Česká prísloví. Sbirka prísloví, př́povídek a pořekadel lidu Českého v Cechách, na Moravě a v Slezsku.Díl I. Přísloví staročeská. Díl I (A-N), díl II (O-Ru). Olomouc: Univerzita Palackého, s. III-XIII.

M o k i e n k o V.M., 2013c, Význam dila Václava Flajšhanse pro evropskou paremiologii. „Acta Slavica Estonica III, SlavicaTartuensia” Х. Славистика в Эстонии и за её пределами. Tartu: Tartu University Press, pp. 109-123.

Mrhačová E., H a rtu ng J., J a n dová E., 2000, Pojmenování zviřat v české a německé frazeologii a idiomatice. Česko-německý slovnik. / Tierbezeichnungen in der deutschen und tschechischen Phraseologie und Idiomatik. Deutsch-tschechisches Wörterbuch. 1. vyd. Ostrava: Ostravská univerzita.

M r h a č o vá E., 2003a, Česká a polská přislovi na bázi zooapelativ. In: Parémie národi̊ slovanských. Mezinárodni konference konaná u př́ležitosti 150. výroči úmrti F.L. Čelakovského. Ostrava: Ostravská univerzita, s. 107-115. 
Mrhačo vá E., 2003b, Názvy zvírat v české, polské a slovenské paremiologii. „Studia Slavica” VII, č. 7, s. 227-241.

Mrha č o vá E.. P o n c z ová R., 2003, Zviřrata včeské a polské frazeologii a idiomatice. 1. vyd. Ostrava: Ostravská univerzitaě.

Mrhač ová E., P o n c zová R., 2004, Lidské tělo v české a polské frazeologii a idiomatice. 1. vyd. Ostrava: Ostravská univerzita.

Mrhačová E., 2008, Předmluva $k$ českému vydání »Slovníku prísloví v devíti jazycich «. In: Slovnik prísloví v deviti jazycich. Praha: Euromedia Group, k.s. Universum, s. 10-13.

Mrhačová E., 2011, Př́roda v české a polské frazeologii a idiomatice. 1. vyd. Ostrava: Filozofická fakulta, Ostravská univerzita.

M r h a č o vá E., 2012, Przyslowia dawniej i dziś. „Bohemistyka” 12, nr 1, s. 61-70.

M r h a č o vá E., 2014a, Parémie - pravé démanty jazyka (místo úvodu). In: Parémie národi̊ slovanských VII. 1. vyd. Ostrava: Filozofická fakulta Ostravské univerzity v Ostravě, s. 11-13.

M r h a č o v á E., 2014b, Srovnávaci slovanská frazeologie a lexikografie na katedře slavistiky Filozofické fakulty Ostravské univerzity. In: Porownawczy apekt leksykografii-teoria i praktyka. 1. vyd. Olomouc: Univerzita Palackého, s. 48-51.

Mrh a č o vá E., 2016, Lexikální analýza západoslovanských parémií a rčení. In: E. Młynarczyk, E. Horyń. Dialog z tradycja. Jezykowe dziedzictwo kultury materialnej. Kraków: Uniwersytet Pedagogiczny im. KEN, s. 317-332.

Mrhačová E., P lesník L., Kupcevičová J., Vaida V., 2017, Východoslovanská prísloví a pořekadla v pohledu do češtiny. Ostrava: Ostravská univerzita.

M r o v ě c o vá L., 2014, Lingvokulturologicheskaja specifika poslovic s komponentom lež v russkom i cheskom jazykach. „Rossica Olomucensia. Časopis pro ruskou a slovanskou filologii" 53, s. 57-71.

Mrověcová L., 2017, Sémantická specifika a variabilita konceptu "pravda $v$ českých a ruských parémiích (kognitivní a kulturologický aspekt). In: Parémie národů slovanských VIII. 1. vyd. Ostrava: Ostravská univerzita, s. 221-231 .

Pavlasová M.,2012, Frazémy biblického pưvodu s vlastními jmény - jsou (ne)aktuálni? (Biblical idioms with proper names - are (not) to date?). „Opera Slavica Slavistické rozhledy” XXII, č. 1, s. 91-99.

S e r g i e n k o O.S., 2016, English and Russian Equivalents to the Proverbs of Czech Active Paremiological Fund. „Russian Linguistic Bulletin” č. 2 (6). s. 76.

S r p o vá H., 2003, Frazeologie a idiomatika jako zdroj aktualizace vžurnalistickém a reklamním diskursu. In: Parémie národi̊ slovanských. Ostrava: Ostravská univerzita, s. 135-142.

S te p a n o v a L.I., 2009, Novoje izdanije slovarja Vaclava Flajšgansa »Česká příslovi «. „Rossica Olomucensia” LIII, č. 3, s. 21-25.
Š i c h o vá K., 2012, [Rec.] H. Sodeyfi, L. Newerkla, Idiomatische Redewendungen, Sprichwörter und Begriffe der Gegenwartssprache in Österreich und der Tschechischen Republik. Frazeologické a idiomatické výrazy v současné češtině a rakouské němčině. Wiesbaden: Harasowit. „Nová čeština doma i ve světě" 1, s. 26-29.

Š i c h o v á K., 2015, Jak frazémy dělají reklamu: Úvahy k typologii frazémů v reklamé. In: Petkevič, V., Adamovičová, A. \& Cvrček, V. (editors), Radost z jazyků. Sbornik přispěvků k 75. narozeninám prof. Františka Čermáka. Praha: NLN, 2015.

Š r á m e k R., 2003, Propria ve frazémech a přislovích. In: Parémie národů slovanských. Ostrava: Ostravská univerzita, s. 61-66.

В а л е н ц о в а М.М., 2015, Человек в чешских и словачких паремиях и фразеологизмах, [в:] Категория оценки и система ценностей в языке и культуре. Москва, с. 203-236.

Дан и л е н ко Л.И., 2006, Коннотативные стереотипь чешской паремиологии, [в:] Проблемы семантики языковых единии в контексте культуры (лингвистический и лингвометодический аспекты): международная научно-практическая конференция (17-19 марта 2006 г.), ред. В.М. Мокиенко и др. Москва-Кострома: Элпис, с. 405-409.

К и р и л л о в а И.В., 2010, Выражение когнитивной оппозиции концептов »ум«, и »ллупость« в русских и чешских паремиях. „Вестник МГОУ - Русская филология”, № 4, с. 64-67.

Ко то в а М.Ю., 2001, Формирование паремиологического минимума славянских языков как основа современной славянской паремиографии, [в:] II Славистические чтения памяти проф. П.А. Дмитриева и проф. Г.И. Сафронова: матеряль международной научной конференции Санкт-Петербург, 12-14 сентября 2000 г.. Санкт-Петербург: Филологический факлтет Санкт-Петербургского университета, с. 103-104.

К о т в в а М.Ю., 2003а, К понятию нормы в паремиологии (на материале славянских языков), [в:] Исследование славянских языков и литератур в высшей школе: достижения и перспективы: информаценние матерялы и те зисы докладов международной научной конферениии (Москва, 21-22 октября 2003 г.). Москва: МГУ, с. 108-111.

Кото в а М.Ю., 2003b, Отражение паремиологического минимума русского языка в других славянских языках, [в:] IV Славистические чтения памяти проф. П.А. Дмитриева и проф. Г.И. Сафронова: матеряль международной научной конференции (Санкт-Петербург, 12-14 сентября 2002 2.). Санкт-Петербург: Филологический факлтет Санкт-Петербургского университета, с. 74-77.

К о т о в а М.Ю., 2003с, Очерки по славянской паремиологии. Санкт-Петербург: Филологический факлтет Санкт-Петербургского университета. 
Ко т о в а М.Ю., 2003d, Роль Ф.Л. Челаковского в современной паремиологии In: Parémie národů slovanských. Ostrava: Ostravská univerzita, s. 35-39.

Ко то в а М.Ю., 2003е, Паремиологический минимум русского языка в сопоставлении с чешским языком. „Bohemistyka” III, nr 2, s. 148-156.

Ко то в а М.Ю., 2004а, К понятию общего ядра наиболее употребительных славянских пословии, [в:] V Славистические чтения памяти проф. П.А. Дмитриева и проф. Г.И. Сафронова. Санкт-Петербург: Филологический факультет Санкт-Петербургского университета, с. 70-75.

Ко то в а М.Ю., 2004b, Славянская паремиология, т. 1 - 231 с., т. 2 - 540 с. Санкт-Петербург.

Ко т о в а М.Ю., 2008, О славянской паремиологии и паремиографии. „Lingu Viva. Odborný časopis pro teorii a praxi vyučování cizím jazykům a češtině jako cizímu jazyku" [České Budějovice] 7.

Ко т о в а М.Ю., 2010а, Лекции по сопоставительной славянской паремиологии Учебное пособие для магистрантов. Санкт-Петербург: Филологический факультет Санкт-Петербургского университета.

Ко т о в а М.Ю., 2010b, Преподавание славянской фразеологии и паремиологии в Санкт-Петербургском государственном университете, [в:] Parémie národi̊ slovanských $V$. Sbornik přispěvkũ z mezinárodní konference konané v Ostravě ve dnech 20.-21.10.2010. Ostrava: Ostravské univerzity.

Ко т о в а М.Ю., 2012, Чешская паремиология (спечкурс), [в:] „ Чешский язык, немеикий язык» - отделение бакалавриата кафедры славянской филологии: Методические рекомендаиии для студентов к учебному плану. Санкт-Петербург: Филологический факультет Санкт-Петербургского университета, с. 134-138.

Кото ва М.Ю., Серг и енко О.С., 2013, Тетради паремиографа. Bыn. 2. Чешские пословичные параллели русских пословии паремиологического минимума: учебные пособие для студентов. Санкт-Петербург: Филологический факультет Санкт-Петербургского университета.

Ко т о в а М.Ю., 2016, О межславянской паремиологической лакунарности (на материале чешских пословичных параллелей русского паремиологического минимума). „Филологические науки. Вопросы теории и практики”, No 2 (4 (58), c. $103-105$

Котов а М.Ю., Ершов а Н.Б., 2017, О выражении противопоставления в синтаксической структуре чешских и словачких пословии (на материале соииолингвистического эксперимента). Международный научно-исследовательский журнал. „International Research Journal”, 10-1-64, c. $76-80$.

Ко то в а М.Ю., Кол па ко в а А.А., 2018, Тетради паремиографа. Выпуск 4. Английские пословичные параллели русских пословии паремиологического минимума: (на фоне болгарских, словачких и чешских пословии). Санкт-Петербург: Контраст.
Моки енко В.М., 2012, Славяно-германские языковые связи в европейском контексте, [в:] Славянский мир: единство и многообразие. Междуна родный научно-практический симпозиум, посвященный Дню славянской письменности. Санкт-Петербург, 25-26 мая 2012 г. Доклады, с. 43-49.

М о к и е н ко В.М., 2013а, Библеизмы в европейской фразеологии и паремиологии, [в:] Die slawische Phraseologie und die Bibel / Славянская фразеология и Библия / Slovanská frazeológia a Biblia. Kollektivmonographie. Greifswald: Universität Greifswald, c. 144-153.

М о к и е н ко В.М., 2013b, Библеизмы как источник европеизации национальной фразеологии и паремиологии, [в:] XLI Международная филологическая конференция, Санкт-Петербург. 26-31 марта 2012 г. Санкт-Петербург: Издательство Санкт-Петербургского университета, с. 111-118.

Моки ен ко В.М., 2014а, Аспекты исследования славянской паремиологии, [в:] Паремиология в дискурсе: Обшие и прикладные вопросы паремиологии. Пословииа в дискурсе и в тексте, Пословииа и языковая картина мира. ЛЕНАНД, с. 4-25.

Мок и е н ко В.М., 2014b, Ваилав Флайшганс - родоначальник Европейского паремиологического союза, [в:] Фразеология и культура. Olomouc: Univerzita Palackého, s. 11-24.

М о к и е н ко В.М., 2014c, Европейские языковые параллели в »Slovníku české frazeologie a idiomatiky«. In: Radost z jazykü. Sbornik $k$ 75. narozeninám prof. Františka Čermáka. Praha: Nakladatelství Lidové noviny, s. 124-137.

М о к и е н ко В.М., 2014d, Параметры славянской паремиографии, [в:] Вестник Новгородского государственного университета им. Ярослава Мудрого. Научно-теоретический и прикладной журнал. Серия »филологические наукищ. Материаль конферениии »Мир русской пословииьл: вечные иенности и новые смыслыщ. Новгородск.

М о к и е н к о В.М.,2014е, Славянская фразеография и паремиография. Коллективная монография, ред. Х. Вальтер, В.М. Мокиенко. Greifswald-SanktPetersburg: Ernst-Moritz-Arndt-Universität Greifswald

Н ау м о в а Н., 2017, Национальная специфика представлений о здоровье в русской и чешской лингвокультурах (на материале паремий и фразеологизмов). „Русский язык и литература в Азербайджане” [Баку], декабрь, c. $26-29$.

С е р г и е н ко О.С.,2007, Трансформачия чешских послович в тексте, [в:] Славянская филология. Вып. 9: Межсвузовский сборник статей, ред. Е.Ю Иванова, Г.А. Лилич. Санкт-Петербург: Издательство Санкт-Петербургского университета, с. 119-132.

С ер г и ен ко О., 2008, Новые элементы традиционных чешских и словачких пословии, [в:] Parémie národů slovanských IV. Ostrava: Ostravská univerzita, s. 234-242. 
С е р г и е н ко О.С., 2009, Редукиия пословии в современных чешском и словаиком языках. „Вестник Санкт-Петербургского университета. Сер. 9, Филология, востоковедение, журналистика", Вып. 4, декабрь, с. 140-146.

С ерги енко О.С., 2010a, Вариантность чешских и словачких послович. Санкт-Петербург, 2010. - 360 с.

С е р г и е н ко О.С., 2010b, Отражение русского паремиологического миниму ма в чешском и словачком языках, [в:] Фразеология, познание и культура: сборник докладов 2-й Международной научной конференция. Белгород, 7-9 сентября 2010 года, т. 1. Фразеология и познание, ред. Н.Ф. Алефиренко. Белгород: Издательство Белгородского университета, c. $380-387$.

С е р г и е н ко О., 2010с, Роль пословичных трансформов в формировании языковой картины мира, [в:] Parémie národi̊ slovanských V. Ostrava: Ostravská univerzita, s. 141-149.

С е р г и е н ко О.С., 2010d, Семантические преобразования пословии (на мате риале чешского и русского языков). „Вестник ЛГУ имени А.С.Пушкина", № 1. Т. 1. Филология, с. 272-280.

С е р г и е н ко О., 2010е, Сокращение компонентного состава пословии в современном чешском и словачком языках, [в:] Phraseologie und Text. Materialien der XXXVIII. Internationalen wissenschaftlich-methodischen Konferenz. Hrsg. A. Savchenko, V. Mokienko, H. Walter. Sankt Petersburg-Greifswald: Fakultät für Philologien und Kunst Staatliche Universität Sankt Petersburg, s. 174-181.

С ергиенко О., 2012, О норме и вариантности в паремиологии, „Оpera slavica", č. 4, s. 1-14.

С ер г и ен ко О, 2014а, Англииизмы в чешской фразеологии и паремиологии, [в:] Stowo. Tekst. Czas XII. Frazeologia widiolekcie i systemach języków stowiańskich. W 200. rocznice urodzin Tarasa Szewczenki, red. Michaił Aleksiejenko, Halyna Biłowus, Mirosława Hordy, Walerij Mokijenko, Harry Walter Szczecin-Greifswald, t. 1, s. 325-333.

С ер г и ен ко О.С., 2014b, Перевод послович в условиях языковой игры (на материале романа 3. Йиротки »Сатурнин»), [в:] Современная филология: теория и практика [Текст]. Материалы XVI международной научно-практической конференции, Москва, 2-3 июля 2014 г. Москва: Издательство »Спецкнига«, с. 144-150.

С ерг и енко О.С. 2014с, Чешско-английские пословичные параллели (на материале активного паремиологического фонда чешского языка), [в:] Современная филология: теория и практика [Текст]. Материалы XV международной научно- практической конференции, г. Москва, 2 апреля 2014 г. Москва: Издательство »Спецкнига«, с. 335-345.

С е р г и е н ко О.С., 2015, Нормативность и вариантность чешских и словачких пословии [монография]. Санкт-Петербург: Санкт-Петербургский университет.
С е р г и ен ко О.С., 2016, Особенности перевода фразеологических единии (на материале повести М.А. Булгакова „Собачье сердие» и ее переводов на чешский и английский языки. „Филологические науки. Вопросы теории и практики" [Тамбов], №4(58): в 3-х ч, с. 144-148.

С т е п а н о в а Л.И., 2003, Очерки по истории чешской фразеологии. Санкт-Петербург: Издательство Санкт-Петербургского университета.

Ф е д о с о в О.И., 2014, Václav Flajšhans, Česká přisloví. Sbirka přisloví, priopovédí a pořekadel lidu Českého v Čechách, na Moravě a v Slezsku, 1-2 Harry Walter, Valerij Mokienko, Ewa Komorowska, Krzysztof Kusal, Русско-немеико-польский словарь активных пословиц (с иноязычными параллелями u историко-культурологическими комментариями). „Slověne”, ą2, c. $217-223$.

Ф е до со в О.И., 2016, Новый мировой порядок и современная славистика. "Slavica litteraria" 19, č. 2, s. 91-98.

Ч е ку лай С̆., Пр охо в а, О., 2014, Деятельностная основа в образовании фразеологических единии с компонентом »стихия» во фразеологических картинах славянских и германских языков. „Rossica olomucensia” LIII, s. $419-422$.

\section{Czech paremiographic collections (including two-language and multi-langua-} ge) of the $21^{\text {st }}$ century

B o č a n k o vá M., 2007, Anglicko-český frazeologicky slovník: ustálené fráze, expresivni výrazy a idiomy, anglicko-česká přislovi. 1. vydání. Praha: Eko Press.

B a c h m a n o vá J., S u k s o v V., 2007, Jak se to řekne jinde. Česká prrísloví a jejich jinojazyčné protějšky. Praha: Euromedia - Knižní klub.

B i t t n e r o vá D., S c h i n d l e r F., 2003, Česká př́sloví: Soudobý stav konce 20. století. 2. vyd. Praha: Nakladatelství Karolinum.

B o čá n k o vá M., K a li n a M., 2004, Česko-anglický slovník idiomů, hovorových výrazů a prísloví. Praha: Ekopress.

Č e r m á k J., Č e r m á k o vá K., 2005, Slovník latinských citátů. 4328 citátů s českým překladem a výkladem. Praha: Euromedia Group k. s. - Knižní klub.

Č e r m á k F., 2009, Slovník české frazeologie a idiomatiky 4 - Výrazy větné. Praha: LEDA.

Č e r m á k F., 2013, Základni slovnik českých přisloví. Praha: Lidové noviny.

F 1 a j š h a n s V., 2013, Česká př́sloví. Sbirka přisloví, průpovédí a pořekadel lidu českého v Čechách, na Moravě a v Slezsku, díl 1-2, ed. V. Mokienko, L. Stěpanova, Olomouc.

K o t o v a M.Yu., 2000, Russko-slavjanskij slovar poslovits s anglijskimi sootvetstvijami. red. P.A. Dmitriev, Санкт-Петербург: Издательство Санкт-Петербургского университета.

Mrhačová E., Świerczyński A., Świerczyńska D., 2008, Slovník príslovív devíti jazycich. 1. vyd. Praha: Euromedia group, k.s. - Universum. 
Mr h a č o vá E. a kol., 2010, Západoslovanské paremiologické dědictví. Ostrava: Filozofická fakulta Ostravské univerzity v Ostravě.

No votná A., 2013, Kdo jinému jámu kopá - Lehko i vážný slovník pořekadel, prirovnání a prísloví. Praha.

N o v o t n á A., 2016, Kdo se směje naposled-Druhý lehko i vážný slovník přirovnání, pořekadel a prísloví. Prahas.

Z e m é n o vá M., 2008, Co na srdci, to na jazyku. Česká př́sloví, přirovnání a rčeni. Brno: Computter Press, a. s.

Žáč e k J., 2001, Kapesní opravník českých př̀isloví; ilustroval Lubomír Lichý. Vyd. 1. Praha: Ivo Železný.

\section{Czech paremiographic collections of the earlier period}

Č e la kovs ký F.L., 1949, Mudrosloví národu slovanského ve př́slovích. Doslov Dvořák, Karel. 3. vydání. Praha: Vyšehrad.

Č e la k ov sk ý F.L., 1978, Mudrosloví národu slovanského ve př́slovich. Doslov Štěpánek, Vladimír. Praha: Československý spisovatel.

Č e rve nk a M., B l aho s lav J., 1970, Česká př́sloví. Připravil Spilka, Josef., Praha: Odeon.

D o b r o v s k ý J., 1963, Českých přisloví sbirka, připravil Heřman, Miroslav. Praha: Nakladatelství Československé akademie věd.

K o m e n s ký J.A., 1954, Moudrost starých Čechi̊, za zrcadlo vystavěna potomkům ed. František Svejkovský. Praha

O u ř e d n ík P., 1994, Aniž jest co nového pod sluncem. Předmluva Alexandr Stich. Praha: Mladá fronta.

Z a o r á 1 e k J., 1963, Lidová rčení. 2. opravené vydání. Praha: Nakladatelství Československé akademie věd.

\section{Bachelor and master qualification papers on Czech paremiology}

\section{Charles University (Prague)}

B e r n á t h o vá D., 2016, Španělská a česká frazeologie a idiomatika s přihlédnutím k publicistickým textưm. Praha, Diplomová práce. Univerzita Karlova, Filozofická fakulta, Ústav románských studií. Vedoucí práce: doc. PhDr. Petr Čermák, $\mathrm{PhD}$.

In d r á k o vá T., 2007, Přiběhy biblických přisloví. Praha, Bakalářská práce. Univerzita Karlova v Praze, Husitská teologická fakulta, Ústav židovských studií. Vedoucí práce: Doc. Bedřich Nosek.

K i p c h a t o v M., 2012, Sémantické charakteristiky paremií s klícovým slovem »voda« (pokus o srovnávací analýzu na přikladu ruštiny a češtiny). Praha. Bakalářská práce. Univerzita Karlova v Praze, Filozofická fakulta, Ústav východoevropských studií. Vedoucí práce: Mgr. Katerina Kedron, Ph.D
K o v a l e v a A.,2016, Frazémy s náboženskými motivy v češtině a ruštině (na základě korpusového výzkumu). Praha. Bakalářská práce. Univerzita Karlova v Praze, Filozofická fakulta, Ústav bohemistických studií. Vedoucí práce: PaedDr Ilona Starý Kořánová

K o v a řík T., 2013, Kůñ v české frazeologii, přislovich a pohádkách. Přispěvek ke studiu jazykového obrazu světa. Praha. Bakalářská práce. Univerzita Karlova v Praze, Filozofická fakulta, Ústav českého jazyka a teorie komunikace. Vedoucí práce: doc. PhDr. Irena Vaňková, CSc., Ph.D.

K o vařík T., 2015, Lidské tělo v české paremiologii (Etnolingvistická studie). Praha. Diplomová práce. Univerzita Karlova v Praze, Filozofická fakulta Ústav českého jazyka a teorie komunikace. Vedoucí práce: doc. PhDr. Irena Vaňková, CSc., Ph.D.

P o d b or s ká B., 2013, K výzkumu stereotypů v českých a německých př́slovích. Praha. Bakalářská práce. Univerzita Karlova v Praze, Pedagogická fakulta, Katedra germanistiky. Vedoucí práce: PhDr. Pavla Nečasová, Ph.D.

P o r t e c h k o G., 2007, Srovnávaci aspekty české a ukrajinské paremiologie. Praha. Diplomová práce. Univerzita Karlova v Praze, Filozofická fakulta, Ústav bohemistických studii. Vedoucí práce: Prof. PhDr. František Čermák, DrSc.

Š r á m k o vá K., 2015, Aktualizace frazeologie v současné češtině. Praha. Diplomová práce. Univerzita Karlova v Praze, Pedagogická fakulta, Katedra českého jazyka. Vedoucí práce: PhDr. Ladislav Janovec, Ph.D.

\section{Masaryk University (Brno)}

Mus il o vá A., 2016, Lidová moudra ve výuce Českého jazyka. Brno. Závěrečná práce. Masarykova univerzita, Pedagogická fakulta, Katedra českého jazyka a literatury. Vedoucí práce: PhDr. Ivana Kolářová, CSc.

P roku din a G. 2013, Кончепт »преступление» в русской и чешской когнитивной картине мира. Brno. Magisterská diplomová práce. Masarykova univerzita, Filozofická fakulta, Ústav slavistiky, Ruský jazyk a literatura. Vedoucí práce: PhDr. Jiří Gazda, CSc.

S i d e ln i k ov a A., 2012, Srovnání ruských a českých paremií se sémantickým komponentem »vztah«. Brno. Magisterská diplomová práce. Masarykova univerzita, Filozofická fakulta, Ústav slavistiky, Ruský jazyk a literatura. Vedoucí práce: PhDr. Jiří Gazda, CSc.

Š p r e ň a r o vá B., 2006, Srbochorvatský překlad přisloví, pořekadel a přirovnán $v$ Jirotkově »Saturninovi«. Brno. Bakalářská práce. Masarykova univerzita, Filozofická fakulta, Katedra slavistiky. Vedoucí práce: Mgr. Pavel Krejčí, Ph.D.

V r šk o vá M., 2007, The Comparison of English and Czech Proverbs. Brno. Diploma thesis. Masaryk University Brno, Faculty of Education, Department of English Language and Literature. Vedoucí práce: prof. PhDr. Josef Hladký, CSc. 


\section{Ostrava University (Ostrava)}

K ö r n y e i o vá L., 2017, Russkie poslovicy i pogovorki o trude, rabote, masterstve i remesle i ih perevod na cheshskij yazyk. Ostrava. Bakalářská práce. Ostravská univerzita, Filozofická fakulta, Katedra slavistiky. Vedoucí práce: PhDr. Jelena Kupcevičová, Ph.D.

P o u r o v á A., 2016, Barevnost světa v české a polské frazeologii. Ostrava. Bakalářská práce. Ostravská univerzita, Filozofická fakulta, Katedra slavistiky. Vedoucí práce: doc. PhDr. Eva Mrhačová, CSc.

S i d k o vá M., 2014, Семейные и родственные отношения в русских и чешских пословииах. Ostrava. Bakalářská práce. Ostravská univerzita, Filozofická fakulta, Katedra slavistiky. Vedoucí práce: $\mathrm{PhDr}$. Jelena Kupcevičová, $\mathrm{Ph} . \mathrm{D}$.

Š 1 e b o d o v á J., 2014, Barvy v české a polské frazeologii. Ostrava. Bakalářská práce. Ostravská univerzita, Filozofická fakulta, Katedra slavistiky. Vedoucí práce: doc. PhDr. Eva Mrhačová, CSc.

\section{Palacky University (Olomouc)}

Grohová M., 2010, The most frequent Czech proverbs in comparison to the English proverbs. Olomouc. Bakalárská práce. Univerzita Palackého, Filozofická fakulta, Katedra anglistiky a amerikanistiky. Vedoucí práce: prof. $\mathrm{PhDr}$. Jaroslav Macháček, CSc.

\section{St. Petersburg State University (St. Petersburg)}

А в е р в я н о в Ю.А., 2009, Пословицы с компонентом с̌as, rok, hodina u их английские соответствия. ВКР бакалавра профиля »Чешский язык, английский языкщ. Санкт-Петербург. Научной руководитель: д.ф.н. М.Ю. Котова.

А л е к с е е в а А.В., 2008, Этнонимы в чешской и английской фразеологии и па ремиологии. ВКР бакалавра профиля »Чешский язык, английский язык«. Санкт-Петербург. Научной руководитель: д.ф.н. М.Ю. Котова.

Т а р а р а е в а О.Н., 2016, Типы преобразований словачких, чешских и английских пословиц в Интернет-пространстве. ВКР магистра профиля магистратуры »Славяно-германская компаративистика«. Санкт-Петербург. Научной руководитель: д.ф.н. М.Ю. Котова.

Ф а е р А.С., 2014, Особенности передачи пословиц и фразеологизмов »властелина колеищ Дж.Р.Р. Толкиена на материале чешских и русских переводов. ВКР магистра профиля магистратуры »Славяно-германская компаративистика«. Санкт-Петербург. Научной руководитель: к.ф.н. О.С. Сергиенко.

Ч уг у н о в а И.С., 2009, Чешские пословицы с анимализмами и их английские соответствия. ВКР бакалавра профиля »Чешский язык, английский языкщ. Санкт-Петербург. Научной руководитель: д.ф.н. М.Ю. Котова.

\section{University of South Bohemia (České Budějovice)}

N ě m c o vá R., 2009, Česká př̉islovi a rčení v průběhu staletí. České Budějovice. Diplomová práce. Jihočeská univerzita, Pedagogická fakulta, Katedra českého jazyka a literatury. Vedoucí práce: PhDr. Milena Nosková, Ph.D.

Z e le n k o vá L., 2009, Př́sloví, rčení a pořekadla v rüzných historických obdobích. Ceské Budějovice. Diplomová práce. Jihočeská univerzita, Filozofická fakulta, Ústav Bohemistiky. Vedoucí práce: doc. PaedDr. Bohumila Junková, CSc.

$\mathrm{Z}$ h u k ov s k у у O., 2013, Русские пословищы и поговорки по теме »работа» и их чешские эквиваленты. České Budějovice. Bakalářská práce. Jihočeská univerzita, Pedagogická fakulta, Oddělení ruského jazyka a literatury. Vedoucí práce: PhDr. Marta Vágnerová, Ph.D. 